\title{
MANAJEMEN PROGRAM PEMBINAAN SANTRI MELALUI METODE POLA DAKWAH DI PESANTREN MODERN
}

\author{
Nurti Budiyanti ${ }^{1}$, Asep Abdul Aziz ${ }^{2}$, Andewi Suhartini ${ }^{3}$, Nurwadjah Ahmad ${ }^{4}$ \\ Email: nurtibudiyanti@upi.edu ${ }^{1}$, asepabdulaziz1993@ gmail.com ${ }^{2}$, andewisuhartini@uinsgd.ac.id ${ }^{3}$, \\ nurwadjahahmad@uinsgd.ac.id ${ }^{4}$ \\ Universitas Pendidikan Indonesia ${ }^{1}$, UIN Sunan Gunung Djati Bandung ${ }^{2,3,4}$
}

\begin{abstract}
Abstrak: Karakter Islam perlu dipupuk sejak dini dalam mengatasi degradasi moral yang kian merebak. Salah satu lembaga pendidikan yang memiliki peran yang besar dalam memupuk karakter ialah pesantren. Pesantren Kreatif IHAQI Boarding School Bandung merupakan salah satu lembaga pendidikan pesantren yang hadir di era revolusi industri 4.0 yang menerapkan metode pola dakwah dalam proses pembelajaran. Penelitian ini menggunakan pendekatan kualitatif dengan metode studi kasus di Pesantren Kreatif IHAQI Boarding School Bandung. Hasil penelitian menggambarkan bahwa pesantren ini memiliki manajeman metode pembelajaran yang khas, yakni menerapkan metode pola dakwah dalam proses pembelajaran. Pada tahap perencanaan, metode ini dinilai sudah direncanakan dengan matang, hal ini terlihat dengan adanya tahap pengorganisasian yang terstruktuk dan sistematis. Adapun tahap pelaksanaannya, metode ini dirasa sudah terlaksana dengan efektif. Namun pada situasi covid-19 berlangsung pelaksanaan menjadi terhambat sehingga kerjasama antara pendidik dan peserta didik dalam mengembangkan metode pola dakwah ini menjadi berkurang. Sementara itu, evaluasi penggunaan metode pola dakwah dalam pembelajaraan di Pesantren Kreatif IHAQI Boarding School ini cukup memberikan kesan yang sangat mendalam kepada seluruh peserta didik untuk mewariskan nilai-nilai Islam. Sehingga seluruh peserta didik mampu meningkatkan potensi dirinya, baik yang berkaitan dengan aspek kognitif, afektif, psikomotorik serta spiritual. Berbagai aspek tersebut sangatlah penting diperhatikan perkembangannya melalui evaluasi proses dan evaluasi hasil yang dilakukan oleh pendidik dalam proses pembelajaran. Dengan demikian manajemen yang baik akan memberikan dampak terhadap tercapainya tujuan pembelajaran.
\end{abstract}

Kata Kunci : Manajemen; santri; metode pola dakwah; pesantren.

Abstrak: The character of Islam needs to be nurtured early on in overcoming increasingly degrading moral degradation. One of the educational institutions that has a big role in fostering character is pesantren. Pesantren Kreatif IHAQI Boarding School Bandung is one of the pesantren educational institutions present in the era of industrial revolution 4.0 that applies da'wah pattern method in the learning process. This research uses qualitative approach with case study method at IHAQI Boarding School Bandung Creative Boarding School. The results of the study illustrate that this pesantren has a typical management of learning methods, namely applying da'wah pattern methods in the learning process. At the planning stage, this method is considered to have been planned carefully, it is seen by the implementation stage that is constructed and systematic. As for the implementation stage, this method is considered to have been carried out effectively. However, in the covid-19 situation, implementation becomes hampered so that cooperation between educators and learners in developing this method of da'wah pattern becomes reduced. Meanwhile, the evaluation of the use of da'wah pattern method in learning in IHAQI Boarding School Creative Boarding School is enough to give a very deep impression to all learners to bequeath Islamic values. So that all learners are able to increase their potential, both related to cognitive, affective, psychomotor and spiritual aspects. These aspects are very important to note the development through process evaluation and evaluation of results carried out by educators in the learning process. Thus good management will have an impact on achieving learning objectives.

Keywords: Management; santri; da'wah pattern method; pesantren. 


\section{A. PENDAHULUAN}

Pendidikan memiliki tanggung jawab yang sangat besar dalam mewujudkan generasi yang berkarakter Islami. Berbagai isu mengenai pendidikan karakter sangat tajam dibicarakan oleh para pakar pendidikan, realita kini menggambarkan semakin derasnya degradasi moral bangsa di setiap jenjang pendidikan. Hal ini disebabkan antara lain karena banyak sekolah di Indonesia hanya sebatas memindahkan ilmu pengetahuan saja, dan belum sampai pada taraf pembentukan moral dan etika (character building) (Syafe'i, 2017). Pembentukan karakter harus dilakukan secara sistematis dan berkesinambungan yang melibatkan aspek knowledge, feeling, loving dan action (Herdiana, 2013). Sehingga pembelajaran tidak bersifat parsial, perlu diupayakan pembelajaran integratif serta komprehensif dalam membantuk karakter Islami (Sukma, 2015); (Budiyanti, Rizal, and Sumarna 2016).

Salah satu institusi pendidikan yang disinyalir telah lama menerapkan pendidikan karakter adalah pondok pesantren. Pondok Pesantren sebagai salah satu sub-sistem Pendidikan Nasional dipandang oleh banyak kalangan mempunyai keunggulan dan karakteristik khusus dalam mengaplikasikan pendidikan karakter bagi peserta didik (Anwar, 2016). Proses pengembangan dunia pesantren harus di dukung oleh pemerintah secara serius sebagai proses pembangunan manusia seutuhnya. Meningkatkan dan mengembangkan peran pesantren dalam proses pembangunan di era otonomi daerah merupakan langkah strategis dalam upaya mewujudkan tujuan pembangunan nasional terutama sektor pendidikan (Ryandono, 2018).

Pesantren sebagai lembaga pendidikan membentuk dan mengembangkan nilai-nilai moral menjadi pelopor sekaligus inspirator pembangkit moral bangsa. Sejatinya perkembangan pendidikan pondok pesantren merupakan perwujudan dari kebutuhan masyarakat akan suatu sistem pendidikan alternative (Alwi, 2016). Pesantren memiliki akar historis yang cukup kuat sehingga menduduki posisi relatif sentral dalam dunia keilmuan (Bashori, 2017). Keberadaan pondok pesantren di Indonesia, dalam perkembangannya sangat berpengaruh terhadap masyarakat di sekitarnya, terutama dalam hal pendidikan (Sulaiman, 2016). Hal ini disebabkan bahwa dari sejak awal berdirinya pesantren disiapkan untuk mendidik dan menyebarkan ajaran Islam kepada masyarakat melalui pengajian, baik dengan sistem tradisional maupun modern (Nihwan, 2017). Hal ini mengisyaratkan bahwa sistem pendidikan pesantren memiliki komitmen kuat dalam mengokohkan karakter manusia agar memiliki pribadi yang utuh di hadapan Allah.

Berdasarkan pemaparan di atas, pesantren telah membuktikan dirinya sebagai suatu lembaga pendidikan Islam yang established (mapan) dan memiliki posisi strategis dalam dunia pendidikan di Indonesia (Sulaiman, 2019), karena memililki peran untuk membentuk karakter manusia utuh. Peran ini dapat terwujud dengan sistem menajemen yang baik, untuk itu penting kiranya penulis melakukan sebuah penelitian terhadap salah satu pesantren yang ada di Indonesia berkaitan dengan manajemen pembinaan santri melalui metode pola dakwah di Pesantren Kreatif IHAQI Boarding School Bandung. Berdasarkan studi pendahuluan pesantren ini merupakan salah satu pesantren yang baru yang berada di wilayah perbatasan antara Kota Bandung dan Kabupaten Bandung yang berdiri pada tahun 2017 yang lalu, pesantren ini dibina oleh salah satu Ustadz ternama yang ada di Indonesia yakni Ustadz Erick Yusuf, beliau merupakan salah satu ulama nasional juga internasional juga seorang publik figur. Pesantren ini telah menerapkan metode pola dakwah dalam setiap proses pembelajaran. Kekhasan inilah yang sejatinya menjadi bahan analisis penulis dalam menggambarkan manajemen pembinaan santri di Pesantren.

\section{B. METODE PENELITIAN}

Studi ini bertujuan untuk memperoleh gambaran mengenai manajemen pembinaan santri melalui metode pola dakwah di Pesantren Kreatif IHAQI Boarding School Bandung. Penelitian ini menggunakan pendekatan kualitatif dengan metode studi kasus. Dalam penelitian dilakukan penelusuran data yang berkaitan dengan manajemen pembinaan santri melalui metode pola dakwah dalam setiap pembelajaran yang dilakukan. Penelitian studi kasus yaitu suatu strategi riset, penelaahan empiris yang menyelidiki suatu gejala dalam latar kehidupan nyata. Strategi ini dapat menyertakan bukti kualitatif yang bersandar pada berbagai sumber dan perkembangan sebelumnya dari proposisi teoretis. Peneliti menghimpun, mengidentifikasi, menganalisis, dan mengadakan sintesis data, untuk kemudian memberikan interpretasi terhadap manajemen pembinaan santri melalui metode pola dakwah di Pesantren Kreatif IHAQI Boarding School Bandung.

\section{HASIL PENELITIAN DAN PEMBAHASAN 1. Pendidikan Berbasis Pesantren Berorientasi Dakwah}

Pendidikan merupaan proses pembinaan dan menumbuhkembangkan potensi yang Allah berikan, agar manusia menjadi paripurna (Budiyanti, Aziz, 
and Palah 2020). Peran pendidikan Islam sangatlah besar dalam membangun karakter bangsa, karena pendidikan Islam memiliki visi dan misi yang hendak di arahkan kepada aktivitas dakwah (Marhamah, Yaya, and Sodiqin 2017). Terutama pendidikan pesantren, erat kaitannya dengan "amal ma'ruf nahyi munkar". Sebagaimana dakwah yang dilakukan oleh para ulama diarahkan dalam rangka mensyiarkan ajaran Allah, melalui ajakan, dorongan, motivasi serta memberikan kebaikan baik oleh lisan, hati serta perbuatan yang dilakukan oleh manusia (Elmansyah, 2016). Terlebih lagi percepatan revolusi industry memberikan peluang untuk berinovasi dalam melakukan dakwah pada proses pembelajaran, khususnya di lingkungan pesantren.

Perkembangan pesantren dari masa ke masa memiliki perubahan yang sangat signifikan, terlebih dunia kini sedang merespon percepatan revolusi industry 4.0 yang memiliki kecanggihan teknologi yang semakin pesat (Lase, 2019). Salah satu lembaga pendidikan pesantren yang hadir di era revolusi industri 4.0 ialah Pesantren Kreatif IHAQI Boarding School Bandung. Pesantren ini adalah pesantren yang memadukan berbagai teknologi modern dalam proses pembelajaran serta mengembangkan berbagai disiplin keilmuan dan keterampilan yang dibutuhkan tanpa menghilangkan nilai-nilai Islam.

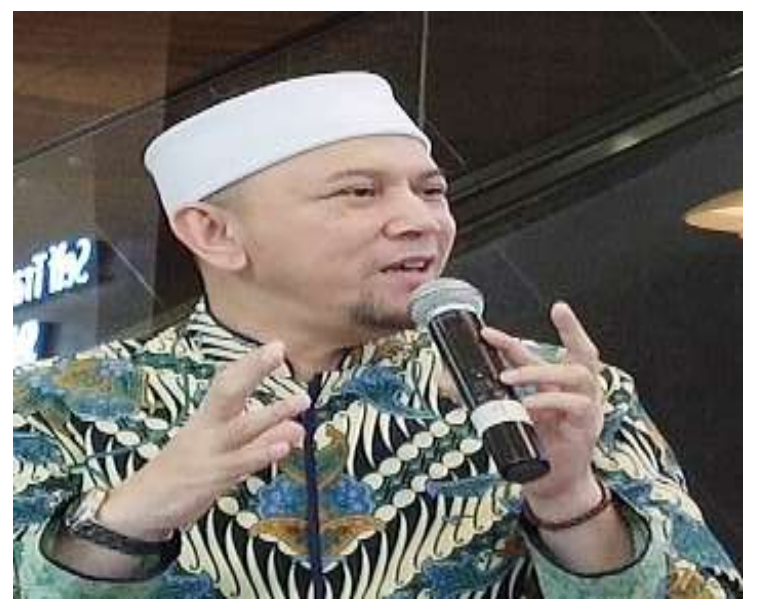

Gambar 1. Pemilik Yayasan Pesantren Kreatif IHAQI Boarding School Bandung

Gambar di atas merupakan tokoh ulama pendiri Pesantren Kreatif IHAQI Boarding School Bandung yang bernama Ustadz Erick Yusuf. Pesantren ini berdiri pada tahun 2017. Ustadz Erick menginginkan lembaga pendidikan komprehensifholistik yang tidak hanya kental dengan nuansa Islami, namun juga melek dengan perkembangan zaman baik dari segi teknologi maupun kreativitas.
Dari ide tersebut, lahirlah Pesantren Kreatif IHAQI Boarding School. Ustadz Erick yang memprakarsai berdirinya pesantren ini benar-benar mematangkan konsep pendidikan yang akan dibangun. Hal ini terbukti dari tenaga didik yang semuanya lulusan S2. Para pengajar yang profesional tersebut juga memiliki kompetensi dan kualifikasi tinggi di bidang pendidikan.

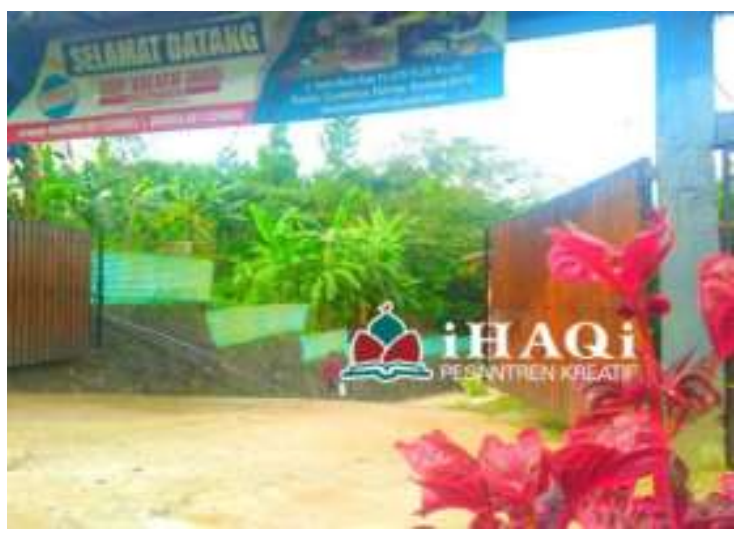

Gambar 2. Lokasi Depan Pesantren Kreatif IHAQI Boarding School Bandung.

Pesantren Kreatif IHAQI Boarding School secara geografis terletak di Kota Madya Bandung, bertepatan di jalan Bukit Raya atas No. 575 Rt 02 Rw 010 Punclut Ciumbeleuit Cidadap Bandung. Keberadaan lembaga pendidikan pesantren ini berada di wilayah yang cukup strategis, berada di perbatasan antara Kota Bandung dan Kabupaten Bandung. Dengan luas tanah $8000 \mathrm{M}^{2}$, status guna pakai dan luas bangunan $2000 \mathrm{M}^{2}$. Pesantren ini sudah memiliki akta pendirian yayasan dan surat izin yang legal, untuk melakukan proses pembelajaran. Adapun jumlah siswa sampai saat ini sudah mencapai 50 siswa, diberbagai tingkatan kelulusan dan kelas. Sistem Boarding School bukan sesuatu yang baru dalam konteks pendidikan di Indonesia. Karena suda sejak lama lembaga-lembaga pendidikan di Indonesia menghadirkan konsep pendidikan Boarding School yang mengadopsi "pondok pesanten" Boarding School yang pola pendidikannya lebih komprehensifholistik lebih memungkinkan untuk menciptakan lingkungan pendidikan yang ideal untuk melahirkan orang-orang yang akan dapat membawa revolusi pergerakan kehidupan sosial, politik, ekonomi dan agama. Sebagaimana hal ini dinyatakan oleh para pakar pendidikan bahwa kemampuan yang harus dihadapi peserta didik dalam menghadari era revolusi indstri ialah kemampuan yang berujung pada karakter abad 21 yakni Critical thinking, Creative, Communication, dan Colaborative (Kembara, Rozak, dan Hadian, 2019);(Septikasari dan Frasandy, 2018). 
Pesantren ini memiliki motto : dengan ilmu dan akhlak sukses dunia akhirat. Dengan visi : agamis, universal dan kreatif. Agamis dalam artian segala idea pikiran dan tindak tanduk serta aktivitas perilaku seluruhnya mestilah terikat pada nilai-nilai agamis yang tentunya akan membawa kebaikan dunia dan akhirat, lalu universal adalah dimana seluruh civitas akademi dari mulai guru, ustadz, staff karyawan, siswa, wali siswa semua mestilah mempunyai wawasan yang universal karena dengannya kita dapat berhubungan dengan baik saling bertukar manfaat atau interkoneksi positif baik terhadap manusia, hewan maupun dengan alam., dan nilai kreatif adalah salah satu sifat Rasul Nabi Muhammad SAW yaitu fathonah. Nilai kreatif yang dapat diartikan cerdas dan penuh dengan ide dan selalu mendapatkan solusi dari berbagai tantangan yang menghampiri. Adapun misi Pesantren Kreatif IHAQI Boarding School dijabarkan sebagai berikut : (1) Menumbuhkan dan meningkatkan keimanan dan ketakwaan. (2) Melaksanakan ibadah dengan benar sesuai dengan tuntutan Nabi Muhammad SAW. (3) Mengaplikasikan nilai-nilai agama dalam kehidupan sehari-hari. (4) Menguasai berbagai disiplin ilmu, baik agama maupun umum. (5) Menjadikan agama dan ilmu sebagai landasan hidup. (5) Menumbuhkan kreativitas dalam kehidupan. (6) Menjunjung tinggi dan mengaplikasikan nilai akhlak. (7) Menumbuhkan kemandirian dalam kehidupan. (8) Meningkatkan potensi keterampilan. Dengan demikian, visi misi pesantren ini mengantarkan kepada tujuan pembentukan akhlakul karimah. Untuk mengantarkan kepada tujuan ini, pendekatan pola dakwah digunakan sebagai metode alternative dalam menanamkan nilai-nilai Islam.

\section{Manajemen Metode Pola Dakwah di Pesantren Kreatif IHAQI Boarding School Bandung}

Manajemen pendidikan pesantren memiliki arti penting dalam rangka memenuhi harapan system pendidikan Islam (Rohman, 2018). Apalagi dalam menghadapi perubahan-perubahan sosio-kultural yang demikian cepat seperti sekarang ini, dibutuhkan fungsi-fungsi manajemen. Menurut Terry, fungsifungsi manajemen yang pokok adalah perencanaan, pengorganisasian, penggerakan, dan pengawasan yang dilaksanakan untuk mencapai tujuan (Salim and Makhshun, 2018). Pesantren Kreatif IHAQI Boarding School Bandung mengimplementasikan pembelajaran menggunakan metode pola dakwah, sebagaimana hal ini diintruksikan oleh Ketua Yayasan dan Kepala Sekolahnya langsung pada tahap perencanaan pelaksanaan proses pembelajaran. Karena pada hakikanya pembelajaran yang harus di sampaikan di lingkungan pesantren adalah sebagai bagian dari aktivitas dakwah yakni menyampaikan kebaikan (Elmansyah, 2016);(Budiyanti, Rizal, and Sumarna 2016);(Rizal 2014). Hal inilah yang harus disadari oleh semua pendidik juga seluruh stakeholder yang ada di lingkungan pendidikan. Dalam rangka memberikan teladan yang baik serta mewariskan nilai-nilai Islam di lingkungan sekolah atau pesantren dengan memperhatikan tahapan dalam manajemen dengan baik (Prayoga 2019; Prayoga and Sulhan 2019).

Pertama: tahap perencanaan, perencanaan penggunaan pola dakwah sebagai metode pembelajaran yang dilakukan oleh pendidik di Pesantren Kreatif IHAQI Boarding School ini sudah direncanakan dengan matang, karena kepala sekolah memberikan monitoring secara langsung pada saat proses pembelajaran. Dengan harapan penggunaan metode pola dakwah sebagai upaya untuk menanamkan nilai-nilai Islam dalam membentuk karakter yang baik pada peserta didik. Penggunaan metode pola dakwah dalam pembelajaran di Pesantren Kreatif IHAQI Boarding School Bandung ini merupakan sebuah tuntutan yang harus dikuasai oleh seluruh pendidik dalam rangka mengembangkan kompetensi pedagogik serta menanamkan nilai-nilai Islam terhadap peserta didik. Sebagaimana dalam Undang-Undang Republik Indonesia Nomor 14 Tahun 2005 tentang Guru dan Dosen dinyatakan bahwa "kompetensi adalah seperangkat pengetahuan, keterampilan, dan perilaku yang harus dimiliki, dihayati, dan dikuasai oleh guru atau dosen dalam melaksanakan tugas keprofesionalannya" (Tabi'in, 2017). Kompetensi guru adalah salah satu faktor yang mempengaruhi tercapainya tujuan pembelajaran dan pendidikan di sekolah (Novauli. M, 2015). Seorang pendidik hendaknya memiliki empat kompetensi yakni kompetensi pedagogik, kompetensi kepribadian, kompetensi sosial, serta kompetensi professional, karena kompetensi ini akan memberikan pengaruh terhadap motivasi belajar peserta didik di dalam kelas (Kosim, 2008);(Sadirman, 2015);(Umami and Roesminingsih, 2014);(Farisi, 2011). Bahkan para ilmuan Islam seperti Al-Ghazali menambahkan kompetensi spiritual sebagai kompetensi utama yang harus ada dalam pribadi seorang muslim. Komptensi ini menjadi inti dari berbagai kompetensi yang ada (Syihabuddin, 2016).

Kompetensi pedagogik adalah kemampuan pemahaman terhadap peserta didik, perancangan dan pelaksanaan pembelajaran, evaluasi hasil belajar, dan pengembangan peserta didik untuk mengaktualisasikan berbagai potensi yang dimilikinya (Indriani, 2015). Kemudian, kompetensi 
kepribadian adalah kemampuan personal yang mencerminkan kepribadian yang mantap, stabil, dewasa, arif dan berwibawa, menjadi teladan bagi peserta didik, dan berakhlak mulia. Adapun kompetensi profesional adalah penguasaan materi pembelajaran secara luas dan mendalam, yang mencakup penguasaan materi kurikulum mata pelajaran di sekolah dan substansi keilmuan yang menaungi materinya, serta penguasaan terhadap struktur dan metodologi keilmuannya (Handini and Widyaningrum, 2016). Sementara itu, kompetensi sosial adalah kemampuan guru untuk berkomunikasi dan bergaul secara efektif dengan peserta didik, tenaga kependidikan, orang tua/wali peserta didik, dan masyarakat sekitar (Mariyana, 2016). Kemudian kompetensi spiritual merupakan sebuah kompetensi untuk senantiasa menanamkan nilai-nilai Islam, yang mana kompetensi inilah yang harus lebih ditekankan oleh setiap pendidikan yang ada di lingkungan pendidikan Islam.

Penggunaan metode merupakan salah satu pengembangan kompetensi pendidik, maka dari itu penggunaan metode yang tepat akan mempermudah peserta didik untuk memperluas wawasan dalam proses pembelajaran (Ulfa, Abdussalam, and Surahman, 2018). Perencanaan penggunaan metode pola dakwah ini bermula dari penjabaran kurikulum sekolah yang memiliki tujuan agamis. Salah satu pencapaian tujuan ini ialah dengan memberikan penekanan kepada pendidik untuk menerapkan metode pola dakwah di lingkungan pesantren. Kepala sekolah memberikan kebijakan untuk memperluas penerapan metode pola dakwah di lingkungan pesantren kedalam kurikulum. Kemudian, pendidik menuangkannya kedalam rencana pelaksanaan pembelajaran. Seluruh pendidik dikerahkan untuk senantiasa mewarnai rencana pelaksanaan pembelajaran tersebut dengan variasi pendekatan, penggunaan media serta taktik dan tehnik pembelajaran yang sesuai untuk mendukung pelaksanaan metode pola dakwah. Adapun durasi pembelajaran yang diberikan kepada setiap pendidik kurang lebih sekitar 2 jam pembelajaran. Dengan harapan setiap pembelajaran apapun yang diberikan harus mampu menanamkan nilai-nilai Islam (Amarullah, Mulyani, and Prayoga 2020; Prayoga et al. 2019; Prayoga, Jahari, and Fauziah 2019).

Kedua: tahap pengorganisasian, pesantren Kreatif IHAQI Boarding School ini memiliki struktur organisasi sebagai berikut :

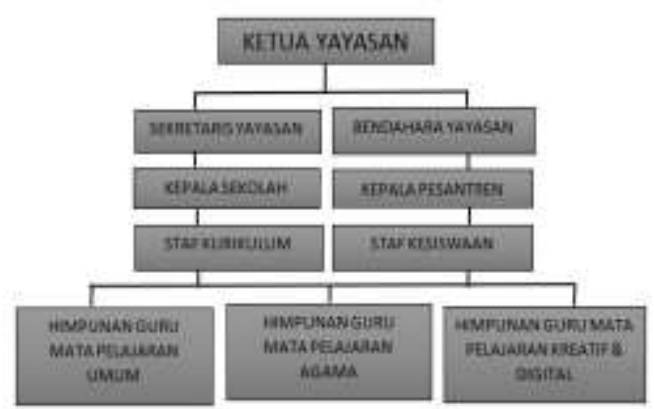

Diagram 1. Struktur Organisasi Pesantren Kraetif IHAQI Boarding School Bandung.

Diagram struktur organisasi Pesantren Kreatif IHAQI Boarding School Bandung di atas merupakan pihak-pihak yang terlibat dalam melaksanakan proses pembelajaran, baik di kelas maupun di luar kelas. Keterlibatan seluruh elemen yang ada di lingkungan pesantren merupakan modal utama dalam mewariskan nilai-nilai Islam sesuai dengn visi misi serta tujuan penyenggaan pendidikan di pesantren Kreatif IHAQI Boading School Bandung.

Ketiga: tahap pelaksanaan, penggunaan metode pola dakwah yang dilakukan oleh pendidik di Pesantren Kreatif IHAQI Boarding School ini dikembalikan kepada masing-masing pendidik dengan di monitoring langsung oleh kepala sekolah sebagai penanggung jawab pelaksana pembelajaran. Pelaksanaan metode pola dakwah dilakukan dengan mengungkap sejumlah ayat yang berkaitan dengan materi pembelajaran yang akan disampaikan. Setelah pendidik menyampaikan ayat tersebut, peserta didik mengungkapkan kembali apa yang disampaikan. Kemudian, pendidik memberikan ibrah dan mauidzah yang terkandung dalam ayat tersebut untuk memunculkan motivasi peserta didik dalam memahami materi yang sedang dipelajari untuk menumbuhan kolaborasi aktif dan komunikasi edukatif dua arah antara pendidik dan peserta didik.

Penggunaan metode yang digunakan di sekolah ini menggunakan pola dakwah yang berorientasi pada metode qur'ani, seperti metode amstal (memberikan perumpamaan), metode targhibtarhib (pemberian reward and punishment), metode uswah hasanah (pemberian keteladanan baik dari sikap, bertutur kata, maupun perbuatan), metode tajribi (pembiasaan), metode ibrah mauidzah (pemberian pelajaran dan nasehat). Perpaduan berbagai metode ini merujuk kepada para ahli yang mengungkapkan metode Islami memiliki peran yang sangat efektif dalam membentuk karakter santri (Nurjannah, 2015);(Pratiwi, Dida, and Sjafirah 2018), yang diarahkan dalam rangka mencapai tujuan pembelajaran. Setiap pendidik di berbagai mata 
pelajaran berkewajiban untuk menerapkan metode pola dakwah ini. Karena seluruh proses pembelajaran harus berorientasi pada penanaman nilai-nilai Islam.

Dalam penerapan metode pola dakwah ini, seluruh pendidik menyajikan beragam media pembelajaran, seperti media alam, media anggota tubuh, media makhluk Allah, media buatan, serta media visial dan audio visual. Seluruh media yang digunakan pun disesuaikan dengan materi yang hendak diberikan kepada peserta didik, dengan mempertimbangkan situasi dan kodisi yang terjadi pada saat proses pembelajaran berlangsung. Materi yang disampaikan oleh seluruh pendidik harus disampaikan dnegan penuh penghayatan. Sehingga teknik pendekatan yang digunakan oleh masingmasing pendidik sangat beragam, seperti teknik penekanan, teknik penghayatan yang dilakukan baik secara verbal maupun non verbal. Dengan demikian, pelaksanaan penggunaan metode dakwah di Pesantren Kreatif IHAQI Boarding School Bandung ini dirasa sudah terlaksana dengan efektif.

Keempat: tahap evaluasi, penggunaan metode pola dakwah dalam pembelajaran di Pesantren Kraetif IHAQI Boarding School Bandung ini perlu dievaluasi. Evaluasi dilakukan oleh kepala sekolah juga kepala pesantren. Evaluasi ini bertujuan untuk melihat sejauh mana efektivitas keberhasilan suatu metode yang digunakan dalam mencapai tujuan pembelajaran. Evaluasi dilakukan dalam dua tahap, yakni evaluasi proses dan evaluasi hasil (Saifulloh and Safi'i, 2017). Evaluasi proses dilakukan oleh kepala sekolah pada saat proses pembelajaran berlangsung yang dilakukan dalam satu pekan sekali. Evaluasi ini bertujuan untuk meningkatkan perbaikan kompetensi pendidik dalam penerapan metode pola dakwah terhadap peserta didik. Oleh karena itu, evaluasi proses ini sangat penting dilakukan sebagai upaya memotivasi pendidik untuk terus mengembangkan keilmuan secara praktis dan kreatif. Adapun evaluasi hasil yang dilakukan oleh kepala sekolah serta kepala pesantren di Pesantren Kreatif IHAQI Boarding School kepada seluruh pendidik dilaksanakan pada saat rapat evaluasi akhir semester dengan mempertimbangkan hasil perkembangan prestasi dari para peserta didik. Seluruh proses evaluasi ini didokumentasikan melalui dokumen sekolah, laporan monitoring serta laporan peningkatan penjaminan mutu.

Berdasarkan hasil penelitian, sebagaimana yang dikemukakan di atas penggunaan metode yang digunakan oleh para pendidik terkesan cukup monoton, sehingga perlu adanya penyeragaman metode agar tepat sasaran dalam mencapai tujuan sekolah yang agamis, universal dan kreatif. Penggunaan metode pola dakwah ini hadir sebagai salah satu solusi agar dapat menanamkan nilai-nilai Islam di lingkungan pendidikan. Penggunaan metode pola dakwah juga dievaluasi dalam berbagai kesempatan seperti rapat dan workhshop pembelajaran yang diselenggarakan oleh kepala sekolah dan kepala pesantren dalam rangka mengupdate serta mendesain konsep pembelajaran yang lebih baik lagi.

Adapun beberapa kendala yang hadir dirasakan oleh pendidik dan peserta didik ialah (1) Pendidik tidak semua faham terhadap penerapan metode pola dakwah, hal ini diakibatkan oleh kompetensi sebagian pendidik yang dirasa kurang mumpuni dalam menerapkan metode pola dakwah (2) Peserta didik tidak semua senang terhadap metode pola dakwah. Berbagai kendala ini disebabkan oleh faktor berikut : (1) Komunikasi tidak terjalin secara komprehensif, sehingga masih ada pendidik yang belum sepenuhnya menerapkan metode pola dakwah dalam setiap proses pembelajaran (2) Sarana prasarana yang kurang mendukung. Tentunya hambatan ini harus dianalisis dengan baik agar tercapai suatu perubahan yang lebih baik lagi. Berbagai kendala yang dikemukakan di atas itulah yang menyebabkan pembelajaran dirasa kurang optimal dalam menanamkan nilai-nilai Islam. Tentunya hal ini disebabkan oleh kurangnya pembinaan yang lebih intensif, kurangnya kerjasama antara pendidik dan peserta didik dalam menjalin komunikasi edukatif dan interaksi emosional yang intens. Maka dari itu perlu ada terobosan baru dalam mengembangkan metode pola dakwah untuk mengatasi berbagai kendala dan hambatan, baik itu pendidik, peserta didik, tujuan, materi, sarana prasaranan, serta komponen lainnya yang harus disesuaikan dalam menunjang proses pembelajaran.

Dengan demikian, penggunaan pola dakwah dalam pembelajaran di Pesantren Kreatif IHAQI Boarding School ini cukup memberikan kesan yang sangat mendalam kepada seluruh peserta didik untuk mewariskan nilai-nilai Islam. Sehingga seluruh peserta didik mampu meningkatkan potensi dirinya, baik yang berkaitan dengan aspek kognitif, afektif, psikomotorik serta spiritual. Berbagai aspek tersebut sangatlah penting diperhatikan perkembangannya melalui evaluasi proses dan evalausi hasil yang dilakukan oleh pendidik dalam proses pembelajaran. Untuk itu evaluasi harus terus dilakukan di pesantren ini dan meng-update kembali penggunaan pola dakwah agar sesuai dengan situasi dan kondisi psikologis perkembangan peserta didik untuk mencapai tujuan pendidikan yang diharapkan.

\section{KESIMPULAN}


Kesimpulan dari hasil penelitian ini ialah Pesantren Kreatif IHAQI Boarding School Bandung merupakan salah satu lembaga pendidikan pesantren yang hadir di era revolusi industri 4.0. Pesantren ini mencoba memadukan berbagai teknologi modern dalam proses pembelajaran serta mengembangkan berbagai disiplin keilmuan dan keterampilan yang dibutuhkan tanpa menghilangkan nilai-nilai Islam, dengan visi agamis, universal dan kreatif, pesantren ini memiliki manajeman metode pembelajaran yang khas, yakni menerapkan metode pola dakwah dalam proses pembelajaran. Pada tahap perencanaan, metode ini dinilai sudah direncanakan dengan matang, karena kepala sekolah memberikan monitoring secara langsung kepada seluruh pendidik, hal ini juga bisa terlihat dengan adanya tahap pengorganisasian yang terstruktuk dan sistematis. Seluruh elemen yang terlibat aktif dalam mendorong pelaksanaan metode pola dakwah ini. Adapun tahap pelaksanaannya, metode ini dirasa sudah terlaksana dengan efektif. Namun pada situasi covid-19 berlangsung pelaksanaan menjadi terhambat sehingga kerjasama antara pendidik dan peserta didik dalam mengembangkan metode pola dakwah ini menjadi berkurang, karena banyak kendala dan hambatan yang terjadi pada saat proses KBM berpindah menggunakan sistem online. Sementara itu, evaluasi penggunaan pola dakwah dalam pembelajaraan di Pesantren Kreatif IHAQI Boarding School ini cukup memberikan kesan yang sangat mendalam kepada seluruh peserta didik untuk mewariskan nilai-nilai Islam. Sehingga seluruh peserta didik mampu meningkatkan potensi dirinya, baik yang berkaitan dengan aspek kognitif, afektif, psikomotorik serta spiritual. Berbagai aspek tersebut sangatlah penting diperhatikan perkembangannya melalui evaluasi proses dan evaluasi hasil yang dilakukan oleh pendidik dalam proses pembelajaran. Dengan demikian manajemen yang baik akan memberikan dampak terhadap tercapainya tujuan pembelajaran.

\section{DAFTAR PUSTAKA}

Alwi, B. Marjani. 2016. "Pondok Pesantren: Ciri Khas, Perkembangan, Dan Sistem Pendidikannya." Lentera Pendidikan: Jurnal Ilmu Tarbiyah dan Keguruan 16(2): 205-19.

Amarullah, Muhamad Matin Shopwan, Mulyani Mulyani, and Ari Prayoga. 2020. "Kepemimpinan Karismatik Kiai Dalam Membangun Budaya Organisasi Di Pesantren Salafiyah." Jurnal Dirasah 03(02): 1-12. https://ejournal.iaifa.ac.id/index.php/dirasah.

Anwar, Abu. 2016. "Karakteristik Pendidikan Dan Unsur-Unsur Kelembagaan Di Pesantren." POTENSIA: Jurnal Kependidikan Islam 2(2):
165 .

Bashori, Bashori. 2017. "Modernisasi Lembaga Pendidikan Pesantren." Jurnal Ilmu Sosial Mamangan 6(1): 47.

Budiyanti, Nurti, ASep Abdul Aziz, and Palah. 2020. "The Formulation Of The Goal Of Insan Kamil As A Basis For The." IJECA (International Journal of Education and Curriculum Application) 3(2): 1-10.

Budiyanti, Nurti, Ahmad Syamsu Rizal, and Elan Sumarna. 2016. "Implikasi Konsep Ūlūl 'Ilmi Dalam Al-Qur'Ān Terhadap Teori Pendidikan Islam (Studi Analisis Terhadap Sepuluh Tafsīr Mu'Tabarah)." TARBAWY: Indonesian Journal of Islamic Education.

Elmansyah, Elmansyah. 2016. "Dakwah Sufistik Di Era Digital." Al-Hikmah.

Farisi, Mohammad Imam. 2011. "Kompetensi Guru Dalam Mewujudkan Pendidikan Berkarakter Dan Berbasis Budaya." Jurnal Teknologi Pendidikan.

Handini, Oktiana, and Dan Ratna Widyaningrum. 2016. "Kontribusi Kompetensi Pedagogik Dan Kompetensi Profesional Guru Terhadap Manajemen Kelas (Studi Di SD Kecamatan Banjarsari Kota Surakarta)." Jurnal Profesi Pendidik 3(1): 36-43.

Herdiana, Iyus. 2013. "The Development of Character Education Model Based on Human's Natural Characteristics." : 264-71.

Indriani, Fitri. 2015. "Kompetensi Pedagogik Guru Dalam Mengelola Pembelajaran IPA Di SD Dan MI.” Fenomena 7(1): 17.

Kembara, Maulia Depriya, Rama Wijaya Abdul Rozak, and Vini Agustiani Hadian. 2019. "Research-Based Lectures to Improve Students' 4C (Communication, Collaboration, Critical Thinking, and Creativity) Skills." 306(Isseh 2018): 22-26.

Kosim, Mohammad. 2008. "Guru Dalam Perspektif Islam." Tadris 3: 14.

Lase, Delipiter. 2019. "Pendidikan Di Era Revolusi Industri 4.0." SUNDERMANN: Jurnal Ilmiah Teologi, Pendidikan, Sains, Humaniora dan Kebudayaan.

Marhamah, Iyam, Yaya Yaya, and Asep Sodiqin. 2017. "Sistem Dakwah Pondok Pesantren AtTawazun Dalam Mengatasi Problematika Santri." Tadbir: Jurnal Manajemen Dakwah 2(4): 329-46.

Mariyana, Rita. 2016. "Kompetensi Guru Dalam Pembelajaran Berbasis Pendidikan Karakter Untuk Anak Usia Dini." PEDAGOGIA Jurnal Ilmu Pendidikan 12(1): 1.

Nihwan. 2017. "Pendidikan Pesantren Dalam 
Mempertahankan Nilai-Nilai Pendidikan Islam." Jurnal Studi Keagamaan, Pendidikan dan Humaniora 4(1): 151-65.

Novauli. M, Feralys. 2015. "Kompetensi Guru Dalam Peningkatan Prestasi Belajar Pada Smp Negeri Dalam Kota Banda Aceh.” Jurnal Administrasi Pendidikan: Program Pascasarjana Unsyiah 3(1): 45-67.

Nurjannah, Rianie. 2015. "Pendekatan Dan Metode Pendidikan Islam (Sebuah Perbandingan Dalam Konsep Teori Pendidikan Islam Dan Barat)." Jurnal: Management of Education.

Pratiwi, Soraya Ratna, Susanne Dida, and Nuryah Asri Sjafirah. 2018. "Strategi Komunikasi Dalam Membangun Awareness Wisata Halal Di Kota Bandung." Jurnal Kajian Komunikasi 6(1): 78 .

Prayoga, Ari. 2019. "Manajemen Program Pembinaan Akhlak Karimah Peserta Didik Melalui Ekstrakurikuler." ISEMA: Jurnal Islamic Education Manajemen 4(1): 93-104. http://journal.uinsgd.ac.id/index.php/isema.

Prayoga, Ari, Jaja Jahari, and Mutiara Fauziah. 2019. "Manajemen Program Vocational Life Skill Pondok Pesantren." J-MPI (Jurnal Manajemen Pendidikan Islam) 4(2): 97.

Prayoga, Ari, Rizqia Salma Noorfaizah, Yaya Suryana, and Mohammad Sulhan. 2019. "Manajemen Pembelajaran Tahfidzul Quran Berbasis Metode Yaddain Di Mi Plus Darul Hufadz Sumedang." Nidhomul Haq: Jurnal Manajemen Pendidikan Islam. 4(2): 140-56.

Prayoga, Ari, and Mohammad Sulhan. 2019. 5 "Pesantren Sebagai Penangkal Radikalisme Dan Terorisme" Dirāsāt: Jurnal Manajemen dan Pendidikan Islam 5(2): 163-177.

Rizal, Ahmad Syamsu. 2014. "Filsafat Pendidikan Islam Sebagai Landasan Mmebangun Sistem Pendidikan Islami.” Jurnal Pendidikan Agama Islam - Ta'lim.

Rohman, Fatkhur. 2018. "Manajemen Kurikulum Dalam Pendidikan Islam." Nizhamiyah.

Ryandono, Muhamad Nafik Hadi. 2018. "Peran Pondok Pesantren Dalam Pemberdayaan Sosial Ekonomi Di Jawa Timur Pada Abad Ke-20." Mozaik Humaniora 18(2): 189-204.

Sadirman 2009: 326. 2015. "Pengaruh Kompetensi Guru Dan Motivasi Belajar Siswa Terhadap Prestasi Belajar Siswa Kelas XI IPS SMA Negeri 17 Medan.” Prosiding Seminar Nasional 978(November): 1-9.

Saifulloh, Ahmad, and Imam Safi'i. 2017. "Evaluasi
Pembelajaran Mata Pelajaran Pendidikan Agama Islam Di Sekolah Menengah Pertama." Educan 01(01): 61-73.

Salim, Samsudin, and Toha Makhshun. 2018. "Manajemen Pesantren Mahasiswa (Studi Kasus Manajemen Pesantren Aji Mahasiswa Al-Muhsin Yogyakarta)." Al-Fikri: Jurnal Studi dan Penelitian Pendidikan Islam 1(2): 58-69.

Septikasari, Resti, and Rendy Nugraha Frasandy. 2018. "Keterampilan 4C Abad 21 Dalam Pembelajaran Pendidikan Dasar." Tarbiyah Al-Awlad VIII(2): 112-22.

Sukma, MRP. 2015. "Lembaga Pendidikan Pembentukan Karakter." Jurnal AlTadzkiyyah: Jurnal Pendidikan Islam 8: 85103.

Sulaiman, Rusydi. 2016. "Pendidikan Pondok Pesantren: Institusionalisasi Kelembagaan Pendidikan Pesantren." 'Anil Islam 9(1): 14874.

2019. "Hakikat Pendidikan Pesantren." Edugama: Jurnal Kependidikan dan Sosial Keagamaan 5(1): 1-29.

Syafe'i, Imam. 2017. "Pondok Pesantren: Lembaga Pendidikan Pembentukan Karakter." AlTadzkiyyah: Jurnal Pendidikan Islam 8(1): 61.

Syihabuddin. 2016. "Pedagogik Spiritual: Telaah Ihwal Landasan Nilai Dan Prinsip Pendidikan Dalam Perspektif Guru Berprestasi." In Konvensi Nasional Pendidikan Indonesia (KONASPI) VIII, Jakarta: KONASPI, 1-8.

Tabi'in, As'adut. 2017. "Kompetensi Guru Dalam Meningkatkan Motivasi Belajar Pada MTsn Pekan Heran Indragri Hulu." Jurnal Pendidikan Agama Islam Al-Thariqah 1(2): 156-71.

Ulfa, Hilma Fauzia, Aam Abdussalam, and Cucu Surahman. 2018. "Metode Pendidikan Tauhid Dalam Kisah Ibrāhīm As. Dan Implikasinya Terhadap Pembelajaran PAI Di Sekolah.” TARBAWY: Indonesian Journal of Islamic Education.

Umami, Dody Rijal, and Erny Roesminingsih. 2014. "Pengaruh Kompetensi Pedagogik Dan Motivasi Kerja Guru Terhadap Prestasi Belajar Siswa Dalam Ujian Nasional (UN) Di SMA Negeri Se Kota Mojokerto." Jurnal Inspirasi Manajemen Pendidikan 3(3): 81-88. 